\section{Association Notices}

\section{AREAS OF SWINDON AND TROWBRIDGE DIVISIONS}

Notice is hereby given by the Council of the British Medical Association to all concerned that it is proposed to transfer the municipal borough of Malmesbury from the area of the Swindon Division to that of the Trowbridge Division.

Any member affected by this proposal and objecting thereto is requested to write to the Secretary of the Association by Oct. 19, 1946, stating the objection and the ground therefor.

Charles Hill,

Sept. 21, 1946 Secretary.

\section{Ophthałmic Group Committee : Correction}

A correction is necessary in the list of members of Committees published on Sept. 7 (p. 77). We have been informed by the Faculty of Ophthalmologists that the names of the six. members of the Ophthalmic Group Committee appointed by the Council of the Faculty of Ophthalmologists should be:

Mr. J. D. M. Cardell, London.

Mr. J. H. Doggart, London.

Mr. R. Affleck Greeves, London.

Mr. E. F. King, London.

Mr. F. W. Law, London.

Mr. J. N. Tennent, Glasgow.

\section{Hospitals Committee : Correction}

Add: "One member to be appointed by the Association of Municipal Specialists."

\section{Diary of Central Meetings October}

17. Thurs. Publishing Subcommittee, 11 a.m. Journal Committee, 2 p.m.

\section{Branch and Division Meetings to be Held}

Coventry Division.-At Coventry and Warwickshire Hospital, Tuesday, Oct. 8, 8.30 p.m. Discussion on the Relationship between the Industrial Medical Officer and the General Practitioner, with reference to the case of open tuberculosis, to be opened by $\mathrm{Dr}$. A. D. Macdonald.

East Kent Division.-At St. George's Hotel, Cliftonville, Thursday, Oct. 10, 8.30 p.m. Address by Dr. I. B. Morris.

East YorKshire Branch.-At " Quern House," Park Street, Hull, Tuesday, Oct. 8, 8.30 p.m. Lecture by Prof. Alan Moncrieff: Child Health.

Richmond Division.-At Richmond Royal Hospital, Friday, Oct. 11, 9 p.m. Dr. Gerald Slot, "Recent Advances in Medical Therapeutics."

\section{Meetings of Branches and Divisions \\ Bath Division}

A meeting of the Bath Division was held on Sept. 25, with Dr. G. D. Steven in the chair, when the following resolution was passed unanimously:

That this meeting strongly recommends to the Council that, in implementing the resolution of the Representative Body (carried on July 24,1946$)$ to take a referendum of the whole profession on the simple issue of whether negotiations with the Minister should take place or not, the referendum should take the following form:

Three separate forms of different colours should be sent to each member of the profession. One form would be headed "Public Services Section," the second "Consultant and/or Specialist Service," and the third "General Practitioner Service." Each form should ask the simple question-" Do you agree to negotiations on regulations on this Section being carried out with the Minister?" Every member of the profession should be asked to return only the form which refers to the Section to which he or she predominantly belongs.

\section{Malaya Branch}

A clinical meeting of the Southern Division, Malaya Branch, was held on July 31,1946 . The subject under discussion was penicillin, and Dr. E. C. Davies, Lieut.-Col. French, and Lieut.-Col Harris spoke. The attendance was 84 .

All general practitioners in Singapore will be able to obtain a textile issue from the Controller of Supplies provided they are sponsored by the Association. The hon. secretary of the Southern Division has undertaken to compile a list of those anxious to secure such textiles, and when complete will arrange for supply to be made.

\section{POSTGRADUATE NEWS}

The Fellowship of Medicine announces: (1) Obstetrics and gynaecology, for general practitioners, daily, Oct. 14 to 19 , at Queen Charlotte's Maternity Hospital, and Chelsea Hospital for Women (2) Week-end course in rheumatism, all day Saturday and Sunday, Oct. 26 and 27, at St. Stephen's Hospital, Fulham Road, S.W.

The University of Leeds Postgraduate Subcommittee announces that it is proposed to hold a two-weeks general refresher course for Class II demobilized medical officers and insurance practitioners, beginning on Monday, Nov. 25. Applications and inquiries should be addressed to the Senior Administrative Officer, School of Medicine, Leeds.

\section{WEEKLY POSTGRADUATE DIARY}

Blackpool: Victoria, Hospital.-Thurs,, 8 p.m., Dr. Cross: Radiotherapy in Gynaecology.

Glasgow University: Department of Ophthalmology.-Wed. 8 p.m., Dr. Michaelson: Proptosis and Exophthalmos.

London School of Dermatology, 5, Lisle Street, Leicester Square, W.C.-Tues., 5 p.m. Dr. A. C. Roxburgh, Cutaneous Syphilis Thurs., 5 p.m. Dr. H. MacCormac, Industrial Dermatitis.

\section{DIARY OF SOCIETIES AND LECTURES}

Royal Society of Medicine

Section of Experimental Medicine and Therapeutics.-Tues. 5.30 p.m. Presidential Address by Prof. H. P. Himsworth : Protein Metabolism in Relation to Disease.

Section of Psychiatry.-Tues., 5.30 p.m. Presidential Address by Prof. Aubrey Lewis: The Education of Psychiatrists.

Section of Physical Medicine.-Wed., 4.30 p,m. Presidential Address by Dr. F. S. Cooksey: The Planning and Organization of Physical Medicine Departments.

Section of Ophthalmology.-Thurs., 5 p.m. (Cases at 4.30 p.m.) Presidential Address by Mr. A. H. Levy: The Aesthetics of Vision. Paper by Mr. John Foster: An Ophthalmic Tour in France and Switzerland.

Clinical Section.-Fri., 5 p.m. (Cases at 4 p.m.)

Chelsea Clinical Society.-At South Kensington Hotel, Queen's Gate Terrace, Tues., 7 p.m. Dinner meeting. Dr. R. Jarman: Modern Anaesthesia,

\section{APPOINTMANTS}

ADDENBROOKE's HOSPITAL, CAMBrIDGE.-Honorary staff appointments : Radiologist, F. R. Berridge, M.B., D.M.R. Surgeon to the Gynaecological and Obstetrical Departments, Oswald Lloyd, M.D. F.R.C.S. Physician. Laurence Martin. M.D., M.R.C.P. Surgeon, B. M. Truscott. M.B.E.. M.B., Bolton ROYal INfirmary.-Honorary Physicians, A. Ingham, M.B., and H. Phillip Goldman. M.B., M.R.C.P.

DAY, F. M., M.R.C.S., D.P.H., Medical Officer of Health. Metropolita Borough of Hammersmith.

EdinbURGH UNIVERSTTY.-D. M. Douglas, Ch.M.. F.R.C.S., lecturer in experimental surgery, University of Edinburgh, deputy director, Research

Royal Liverpool United Hosprtal.-Appointments to Honorary Medica and Surgical Staff at Liverpool Royal Infirmary: Dental Surgeon, G. Graham Macphee, M.D.. L.D.S. Assistant Physician for Tropical Diseases. D. R Dermatologist, G. W. Bamber, M.D., F.R.C.P.

St. Thомas' Hospital, S.E.-Honorary appointments. Obstetric Physician, R. K. Bowes, M.D., M.S., F.R.C.S. Orthopaedic Surgeon, G. Perkins, M.Chir. F.R.C.S.

\section{BIRTHS, MARRIAGES, AND DEATHS}

The charge for an insertion under this head is 1us. 6d. for 18 words or les. Extra words 3s. 6d. for each six or less. Payment should be forwarded with the notice, authenticated by the name and permanent address of the sender. morning.

\section{BIRTHS}

Cirns.-On July 12,1946, at Kingston-on-Thames, to Theresa, wife of Dr. R. J. Cairns, a son-Andrew John.

EARDLEY.-On September 21. 1946, at 23, Keighley Road, Colne, Lancs, to Catherine Vera, wife of A. W. R. Eardley, M.B., Ch.B.(Sheff., 1931), twinsAlan Christopher Stenton and Catherine Rosalind.

JACOBS.-On September 22, 1946, at Hammersmith Hospital, to the wife of Dr. A. L. Jacobs (Dr. Lusia Frank), a daughter.

Orton-On September 26, 1946, to Drs. Richard and Betty Orton, 30, Corn wallis Crescent, Clifton, Bristol, a daughter.

\section{MARRIAGE}

Edwards-AdaMs.-On September 17, 1946, at Stenhouse Church, Capt. Frank Edwards. A.D. Corps, of "Innervar," Larbert, Stirlingshire, to Capt. Sally Adams, R.A.M.C., of Blackstown House, Broughane, Ballymena, N. Ireland

\section{DEATHS}

Euliot.-On September 7, 1946, Henry P. Elliot, born 1871, M.B., C.M. 1894, Queensland ad eum grad. Practised mostly in Australia for 51 years.

Evans.-On September 26, 1946, at Oxford, Brenda, wife of Gordon. Bvans; 